\title{
NATIONAL SECURITY REVIEW OF FOREIGN INVESTMENTS IN HUNGARY
}

\author{
Károly László Simon ${ }^{1}$, Katalin Gombos ${ }^{2}$
}

\begin{abstract}
Screening mechanisms as investment policy measures keep gaining importance worldwide. In October 2018, the Hungarian Parliament also adopted rules on the national security review of foreign investments. This paper intends to present the newly introduced Hungarian screening mechanism which is applicable from 1st January 2019. The goal of this article is to determine how the established Hungarian FDI system can be typified, integrated into an existing regulatory model, or whether it carries elements of a multilayered system, possibly providing a completely new approach to FDI. We conclude that Hungarian new rules on foreign investment control have become more transparent and coherent than in the past. Nonetheless the review process suffers from a number of shortcomings that may hinder the full accomplishment of the predictability and the effectiveness.
\end{abstract}

\section{Keywords}

Foreign Investment, Investment Screening, National Security Review, Hungary

\section{Introduction}

Screening mechanisms as investment policy measures keep gaining importance worldwide. More and more countries have introduced new screening frameworks expanding disclosure obligations of foreign investors and extending statutory timelines of screening procedures or have adopted new civil, criminal or administrative penalties for not respecting notification obligations. This paper intends to present the newly introduced Hungarian screening mechanism within this framework.

The timeliness of the study is given by the fact that detailed analyses of this screening mechanism have not yet been performed. The motivation of the research was also to examine how the new Hungarian regulation fits into the EU regulation. In addition to presenting the Hungarian system, we wanted to explore possible points of contention. Our

\footnotetext{
${ }^{1}$ National University of Public Service, Ludovika tér 2, 1083 Budapest, Hungary. E-mail: Simon.Karoly.Laszlo@uni-nke.hu.

${ }^{2}$ National University of Public Service, Ludovika tér 2, 1083 Budapest, Hungary.

E-mail: Simonne.Gombos.Katalin@uni-nke.hu.
} 
hypothesis was that only national regulations based on the rule of law criteria would be appropriate. As the subject is fundamentally part of the common commercial policy of the EU, the exclusive competence of the EU calls for greater attention to be paid to defining the regulatory framework of the Member States.

Currently, screening frameworks can only be examined by a descriptive method. The approach used in this article is sufficiently effective if the definitional issues that arise in this area of law are clarified and some sort of classification is done. The practice of other countries is of great relevance to our topic, thus, the international comparative law method helps examine some of the delimitation issues, leading us to the right conclusions. Based on their features, this paper presents the screening mechanisms for foreign investments applied in the world in three groups and determines the place of the Hungarian regulation and the forthcoming EU regulation in this system.

Today, there is still only a limited amount of analytical data available on the effects of the Hungarian rules, so in addition to the descriptive-epistemological method, this article applies a chain of "top-down" reasoning that allows deductive conclusions to be drawn. The paper works with premises that can be justified by a syntactic method. A special feature of the topic is a strong procedural approach, and the paper specifies the rules of the Hungarian screening mechanism for the purpose of raising dilemmas that need to be addressed by case law in the future. Therefore, its conclusions and hypotheses are mainly theoretical.

To substantiate these contentions, the rest of the article is arranged as follows: section II examines the national security review systems and categorizes the Hungarian model. In addition, this part deals with the EU regulation, too. Section III delves into the key features of the Hungarian rules. The paper ends with concluding remarks in section IV.

\section{Screening Mechanisms for Foreign Investment}

As Chinese companies are likely to continue with their investments in the future, European Union countries are facing a dilemma between encouraging and welcoming them, on the one hand, or safeguarding strategic sectors and industries of their national economies, on the other. ${ }^{3}$ In recent years, FDI screenings have become a relevant factor for global transactions at international, regional (European Union) and national level. ${ }^{4}$ Albeit diverse in their nature and procedures, these mechanisms aim to address challenges posed by FDI in sectors that are deemed either sensitive or strategic to economy, national security and public interest.

Investment review mechanisms can be broadly categorized in three groups, depending on the scope and depth of the review process. First, some countries apply cross-sectoral screening procedures with broad and flexibly defined review criteria, such as national security (United States), public interest (United Kingdom) or the fundamental interests of society (Finland). Second, foreign investment screening may target specific sectors clearly identified in national legislation as sensitive (India, Japan, Russia, Lithuania, Hungary).

\footnotetext{
${ }^{3}$ Nicolas (2014), 103-125.; Meunier (2014a), 283-302.; Ma and Overbeek (2015), 441-454.; Casarini (2016), 95-108.; Matura (2017), 74-79.; Szunomár and Peragovics (2019), 2-8.

${ }^{4}$ World Investment Report 2019, United Nations Conference on Trade and Development, New York, 2019, p. XI.
} 
This approach provides more predictability for foreign investors, as an anticipated engagement in a sector not listed in the legislation will not be subject to a review. The sectors that most frequently fall under these screening procedures are public utilities, telecommunications, transportation and media; the manufacturing sector is rarely included, though. The third approach focuses predominantly on investments in key technologies considered to be of high economic value, independent of the sector in which the investment is made (China, Republic of Korea). This type of screening may be applied in addition to crosssectoral or sector specific reviews. 5

According to the world investment reports of UNCTAD, the EU has one of the world's most open FDI regimes and has been a main source and destination of FDI. However, until now, the EU has had no single centralised FDI screening mechanism on grounds of security or public order. In September 2017, the European Commission presented a proposal for an EU Regulation establishing a framework for screening of foreign direct investments into the European Union. After more than a year of negotiations, in December 2018, the Commission, the European Parliament and the Council of the European Union reached an agreement on the final text for the FDI Regulation that was adopted on 19 March 2019 and officially entered into force on 10 April 2019. ${ }^{6}$ The FDI Regulation shall apply from 11 October 2020. ${ }^{7}$ The FDI Regulation is without prejudice to the right of Member States to restrict cross-border investments on grounds of public policy or public security. ${ }^{8}$

As of today, fourteen out of the twenty-seven Member States have national (decentralised) screening procedures in place within the European Union. ${ }^{9}$ They developed different or a combination of approaches to control foreign investments. In these Member States, the most common sector to be scrutinised is military and defence. However, for mergers and acquisition projects the broadly defined area of "critical infrastructure" 10 is even more relevant. Usually, it includes the energy, water, telecommunications, healthcare, transport and infrastructure, and certain IT and finance infrastructure sectors. In addition, dataintense emerging and foundational technologies in the IT sector have also gained attention recently. Authorities are focusing more and more on areas such as artificial intelligence, autonomous vehicles, robotics, and the "internet of things". 11

\footnotetext{
${ }^{5}$ World Investment Report 2018, United Nations Conference on Trade and Development, New York and Geneva, 2018, pp. 160-161.

${ }^{6}$ Regulation (EU) 2019/452 of the European Parliament and of the Council of 19 March 2019 establishing a framework for the screening of foreign direct investments into the Union (hereinafter referred to as: the FDI Regulation); OJ L 79I, 21.3.2019, pp. 1-14.

${ }^{7}$ Article 17 of the FDI Regulation.

${ }^{8}$ Article 1(2), (3) of the FDI Regulation; Bian (2020), paras. 7.2.3. and 7.2.4.1.

${ }^{9}$ Austria, Denmark, Germany, Finland, France, Latvia, Lithuania, Italy, the Netherlands, Poland, Portugal, Romania, Spain, and Hungary. The Commission published a list of FDI screening mechanisms notified by Member States on 24 June 2019 (http://trade.ec.europa.eu/doclib/docs/2019/june/tradoc_157946.pdf); last update: 15 April 2020.

10 "Critical infrastructure" was first defined in Directive 2008/114/EC as an asset, system or part thereof which is essential for the maintenance of vital societal functions, health, safety, security, economic or social well-being of people. (Council Directive 2008/114/EC of 8 December 2008 on the identification and designation of European critical infrastructures and the assessment of the need to improve their protection, OJ L 345, 23.12.2008, pp. 75-82.)

${ }^{11}$ Bian (2020), para. 7.2.6.
} 
Asian foreign direct investments have played a vital role also in the Hungarian economic life, nonetheless, FDI inflows were only marginally restricted. ${ }^{12}$ Until the end of 2018, the investment screening procedure was included in the national Acts on natural gas and electricity in the form of a preliminary authorisation procedure with regard to specific infrastructures relevant for the security of supply. However, in the above-described international and European context, the Hungarian Parliament has passed an Act establishing a national investment screening procedure. Act LVII of 2018 on Controlling Foreign Investments Violating Hungary's Security Interests (hereinafter Act) entered into force on 1st January 2019. ${ }^{13}$ This Act is complemented by a Government Decree concerning the implementation of the new Act. ${ }^{14}$ After the entry into force of the Act and the Government Decree, the special authorisation procedure has been extended to other sectors and the review process has been tightened.

\section{The Key Features of the Hungarian Screening Mechanism}

\section{The character of the Hungarian system}

Each national legislation provides certain FDI screening criteria, against which the governments assess potential risks associated with foreign mergers and acquisitions. A truly "open door" policy towards foreign investments does not seem to exist in the world in the 21 st century. ${ }^{15}$ The time when warfare only consisted of guns and bullets has passed; nations were obliged to realize that the most destructive weapon may be money and trade in the new millennium, ${ }^{16}$ international trade may also create economic vulnerability and implies national security risks. ${ }^{17}$ Most of the newly introduced investment screening systems reflect the national security concerns of host countries ${ }^{18}$, so does the Hungarian regulation. In fact, the new Hungarian law set up a national security review regime for foreign investments in strategically sensitive activities such as defence, dual-use products, electronic communication etc.

"National security is an ambiguous term", states Stapleton. ${ }^{19}$ Usually, countries do not provide a "clear-cut definition" of national security in relation to foreign investment; also the term used for "national security" varies from jurisdiction to jurisdiction: expressions such as "public order", "public safety", "public policy", "national security interest" are

\footnotetext{
${ }^{12}$ Gubik et al. (2020), 240-243.; Varga (2018), 115-118.

${ }^{13}$ The full text of the Act is available in Hungarian at: http://njt.hu/cgi_bin/njt_doc.cgi?docid=210606.359458. The unofficial English translation of the full text of the Act can be found at: https://trade.ec.europa.eu/doclib/docs/ 2019/june/tradoc_157938.pdf (Annex A).

${ }^{14}$ Government Decree 246/2018 (XII. 17.) on the Implementation of Act LVII of 2018 on Controlling Foreign Investments Violating Hungary's Security Interests (hereinafter referred to as: the Government Decree). The full text of the Government Decree is available in Hungarian at: http://njt.hu/cgi_bin/njt_doc.cgi?docid=211634.361766. The unofficial English translation of the text of the Government Decree can be found at: https://trade.ec.europa.eu/doclib/docs/2019/june/tradoc_157938.pdf (Annex B).

${ }^{15}$ Salacuse (2013), 87.

${ }^{16}$ Stapleton (2015), 1647.

${ }^{17}$ Dixit (2011), 195.

${ }^{18}$ Mota (2018), 455.

${ }^{19}$ Stapleton (2015), 1647.
} 
applied. The lack of clear definitions as well as the broad interpretation of the concept grant the government enough flexibility and discretion to stop non-desired FDI. Obviously, states have sovereign right to control FDI flux in principle. The OECD, however, elaborated Guidelines for Recipient Country Investment Policies relating to National Security that identify several essential principles to be taken into account in relation to the development of any evaluation system of FDI. These principles are the following: non-discrimination, transparency, proportionality and accountability. ${ }^{20}$

Similarly, the Hungarian Act does not provide a uniform definition of "national security" but, for transparency reasons, mentions some factors that may be considered relevant for security interests. The substance of the Hungarian screening regime can be tackled by focusing on four points: the origin of the investment (ratione personae), the nature of the investment and the threshold (ratione materiae), the target of the investment (regulated sectors) and last but not least the review process.

\section{Ratione personae}

The origin of the investment and the quality of the investor are relevant, for instance, in order to assess its potential conflict with national security. In this context, the most fundamental task is to define the term foreign investor. This definition is dealt with by the Hungarian Act in two ways.

First, FDI has been traditionally considered "foreign" because of the nationality of the investor. ${ }^{21}$ Nonetheless, the national regulation had to take into account the membership of Hungary in the European Union (hereinafter referred to as EU) and the European Economic Area (hereinafter referred to as EEA) because the free movement of capital, including the FDIs, shall not be restricted within these communities. ${ }^{22}$ Furthermore, Article 207(1) TFEU provides that EU acts concerning "foreign direct investment" fall within the common commercial policy and, consequently, the EU has exclusive competence to approve any commitment vis-à-vis a third State relating to investments made by natural or legal persons of that third State in the EU and vice versa. ${ }^{23}$ For this reason, the Hungarian Act excludes the application of the screening mechanism for investments originating from other member states of the EU or the EEA. Therefore, pursuant to the Act, "foreign investor" means any citizen, legal person or other organization registered in any state outside of the EU, the EEA or Switzerland. Compared with the Proposal, the Act has an extended personal

\footnotetext{
${ }^{20}$ Organisation for Economic Co-operation and Development, Recommendation of the Council on Guidelines for Recpient Country Investment Policies relating to National Security, C(2009)63, Paris, OECD, 2009, Annex 1.; Organisation for Economic Co-operation and Development, Accountability for Security-Related Investment Policies, Paris, OECD, 2008, p. 4.; De Luca (2015), 180-181.

${ }^{21}$ Mota (2018), 446.

${ }^{22}$ Articles 63 to 66 of the Treaty on the Functioning of the European Union (TFEU); Articles 40 to 45 and Annex XII of the Agreement on the European Economic Area (EEA Agreement); see the case law of the European Court of Justice concerning this matter: judgments of 12 December 2006, Test Claimants in the FII Group Litigation, C-446/04, EU:C:2006:774; of 23 October 2007, Commission v Germany, C-112/05, EU:C: 2009:193; of 26 March 2009, Commission v Italy, C-326/07, EU:C:2009:193; of 24 November 2016, SECIL, C-464/14, EU:C:2016:896.; See Bian (2020), para. 7.2.2.; De Luca (2015), 178-205.

${ }^{23}$ Opinion 2/15 of the European Court of Justice, EU:C:2017:376, paragraphs 81 and 82.
} 
scope: it applies not only to an investor (citizen, legal person or other organization) from outside of the EU, the EEA and Switzerland, but also to a company established in the EU, Switzerland or an EEA member state, if it has a controlling shareholder from outside of the EU, Switzerland or the EEA. ${ }^{24}$ Thus, all companies from third countries that have economic interests in Hungary might be affected by the Act. According to statistical data relating to FDI inward flows, the main investing third countries in Hungary are the United States, Japan, South Korea and China.

Second, regarding the influence and the quality of the foreign investor, it may also cover a legal entity registered domestically, in another member state of the EU, the EEA or in Switzerland in which a non-EU, non-EEA or non-Swiss legal or natural person has a controlling interest. Majority control means a relationship where a natural or legal person (the so-called controlling shareholder) controls over fifty per cent of the voting rights in a legal person, or in which it has a dominant influence. ${ }^{25}$ The controlling shareholder has a significant influence on a legal person if it is a member of or shareholder in that company and $a$ ) it has the right to appoint and recall the majority of the executive officers or supervisory board members of the legal person; or $b$ ) other members of or shareholder in that legal person are committed under agreement with the holder of a participating interest to vote in concert with the holder of a participating interest, or they exercise their voting rights through the holder of a participating interest, provided that together they control more than half of the votes. ${ }^{26}$

\section{Ratione materiae}

As stated in its title, the Act shall be applied to "foreign investments". Determining the actual and precise concept of "foreign direct and indirect investment" would pose inevitable methodological challenges that exceed the framework of this analysis. ${ }^{27}$ Instead, it might be worth specifying what is really meant by the term foreign investment in the context of the Act. In addition to the nature of the foreign investment, the amount of the investment or the future degree of involvement of the foreign investor in a specific firm is also relevant as thresholds for invoking national security concerns are usually set in FDI review systems on national security grounds. ${ }^{28}$

Pursuant to the Act, the acquisition of ownership or interest in a target company or the establishment of a branch office are covered by this term. ${ }^{29}$ Furthermore, extending the activity of the company to the regulated sectors as well as the acquisition of the right to operate also fall under the scope of the Act. ${ }^{30}$ Hence, not all foreign investors are obliged to declare their activities but only those that operate in the ways described by the Act. ${ }^{31}$

\footnotetext{
${ }^{24}$ Art. 1 (1) of the Act.

${ }^{25}$ Section 8:2 (1) of the Hungarian Civil Code.

${ }^{26}$ Section 8:2 (2) of the Hungarian Civil Code.

${ }^{27}$ World Investment Report 2006, UNCTAD, Methodological Note; OECD Benchmark Definition of Foreign Direct Investment. Fourth Edition, 2008.

${ }^{28}$ Mota (2018), 450.

${ }^{29}$ Art. 1 (2), Art. 2 (1)-(3) of the Act.

${ }^{30}$ Art. 3-4 of the Act.

${ }^{31}$ Gáspár-Szilágyi (2019), 10.
} 
Firstly, a notification to the Minister of the Interior (hereinafter referred to as: the Minister) is required where a foreign investor acquires ownership in a Hungarian company in a regulated sector. It covers both direct and indirect ownership exceeding 25\% (10\% for a public limited company) or significant influence (see above) in a Hungarian target entity, or that as a result of the acquisition, the ownership of foreign investors would exceed $25 \%$ in the Hungarian target entity (except for public limited companies). ${ }^{32}$ This rule only takes into account the share of ownership in the target company, but not the voting rights or other legal and financial instruments suitable for exercising decisive influence. A minority shareholder may have over half of the voting rights and, therefore, the foreign investor that acquires less than $25 \%$ of the shares is able to exercise a dominant influence over the Hungarian company. ${ }^{33}$ It is not difficult to circumvent the Act via shady ownership chains that may optionally increase national security risks and are difficult to detect. ${ }^{34}$ By way of example, there is no obstacle to hiding behind a person that is qualified non-foreigninvestor. The question also arises whether a minority foreign shareholder not covered by Article 2 of the Act should be obliged to declare its activities if it pays a substantial portion of a Hungarian company's debts. ${ }^{35}$

Secondly, the opening of a branch by a foreign investor for the purpose of conducting activities in one of the regulated sectors also falls under the notification obligation. Such a local branch may be established by a foreign investor only if the foreign investor fulfils the necessary conditions laid down by Hungarian law for the opening of a branch as well as its notification obligation and obtains the minister's confirmation. ${ }^{36}$

Thirdly, it is possible that a company in which foreign investors acquired the above ownership stakes or hold a significant influence carries out an economic activity in Hungary and intends to begin offering services in any of the regulated sectors. In such a case, the operating company, after the entry of the new activity in the register of companies, is obliged to notify the registration to the Minister. ${ }^{37}$ The activity must not be carried out unless the Minister has confirmed the notification. ${ }^{38}$

Finally, the FDI Act specifies that foreign investors may only obtain the right to operate and to use the infrastructure, equipment and tools that are essential for carrying out the activities of national security interest in the sensitive sectors. ${ }^{39}$ The right to operate may start after receiving the confirmation of the acknowledgement of the notification.

\footnotetext{
32 Art. 2 (1) a), Art 2 (2) of the Act.

33 Gáspár-Szilágyi (2019), 10.

34 Peragovics (2019), 10.

35 Gáspár-Szilágyi (2019), 11.

36 Art. 2 (3) of the Act. Establishment of a branch in Hungary is regulated by the Act No CXXXII of 1997 on branches and commercial agencies of undertakings which have their registered office abroad.

37 Art. 4 (2) of the Act.

38 Art. 4 (1) of the Act.

39 Art. 3 of the Act.
} 


\section{Regulated sectors and activities}

Following international trends, the Act focuses on which foreign investments could affect national security and critical infrastructure, the goal of the Hungarian regulation being to retain control over certain key areas of the national economy and to protect "flagship" companies from predatory foreign investments. ${ }^{40}$ The Act is not of general scope, the notification obligation applies only to some priority sectors of the national economy. ${ }^{41}$ The exact activities and services within the regulated sectors are specified by the Government Decree. $^{42}$

It is self-evident that defence and military-related industries are protected by this regulation. These sectors cover the production of firearms, ammunition (except for historical munition), parts of weapons and military tools requiring a license. ${ }^{43}$ Similarly, the manufacture of certain secret service tools is bound by the preliminary notification obligation. The scope of the Act also includes the manufacture of dual-use items which matter has been regulated at EU level too. The manufacture of products enumerated in Annex I to the Council Regulation (EC) No 428/2009 setting up a Community regime for the control of exports, transfer, brokering and transit of dual-use items falls under the notification obligation pursuant to the Hungarian law.

The scope of the Act comprises the offering of financial services and the operation of payment systems but the range of the security screening of this field is significantly reduced by the Government Decree. As a result only data processing by a financial institution operating the central credit information system and the operation of payment systems - excluding the operation in respect of payment transactions exclusively executed with cash-substitute payment instruments - fall under the screening obligation.

One of the other classical fields of security review is public utilities: offering electricity services ${ }^{44}$, natural gas services ${ }^{45}$, water public utility services ${ }^{46}$, or electronic communications services ${ }^{47}$ belongs to the regulated sectors. ${ }^{48}$ The affected activities are specified by the Government Decree: transmission and distribution of electricity, system operation, production of electric energy by a production licence holder with a production licence for a power plant with a nominal performance capacity of at least $50 \mathrm{MW}$; distribution, storage, delivery of natural gas, system operation; outsourcing and development of public water supply; provision of electronic communication services for the provision of which the electronic communication network operated includes system elements of vital national or European importance.

\footnotetext{
${ }^{40}$ Mota (2018), 450.

${ }^{41}$ Art. 2 (4) of the Act.

${ }^{42}$ Annex 1 to the Government Decree.

${ }^{43}$ Act No XXIV of 2014 on Firearms and Ammunition.

${ }^{44}$ Act No LXXXVI of 2007 on Electric Energy.

${ }^{45}$ Act No XL of 2008 on Natural Gas Supply.

${ }^{46}$ Act No CCIX of 2011 on Water Utility Supply.

${ }^{47}$ Act No C of 2003 on Electronic Communications.

${ }^{48}$ Smart technology and artificial intelligence often appear among the protected areas. See Shields (2018), 279-308.
} 
Finally, the establishment, development or operation of electronic information systems is also a sector protected by the Act. ${ }^{49}$ The activities subject to the notification obligation are cooperation in the establishment, operation, auditing, maintenance or repair of electronic information systems, participation in an investigation into a security event and the performance of a fragility test.

\section{The review process}

Although the review can be launched ex officio (administrative control), it is in principle a voluntary process triggered by the foreign investor (notification).

The notification shall be made in writing in Hungarian language, addressed to the Minister of the Interior (hereinafter referred to as the Minister) within ten days from the signing of the contract or pre-contract targeting acquisition of ownership or the right to operate. The registration of a newly adopted activity in the company registry shall be notified to the Minister within ten days from its registration. ${ }^{50}$ In the event of a natural person foreign investor, the notification shall include their natural personal identification data, residence or accommodation in Hungary or place of permanent or temporary residence abroad, nationality and contact details for written communication. In case of a legal person or other organization, the obligatory elements of the notification are their name, seat and seat of branch in Hungary, the specification of the state performing the duties related to their official registration and their contact details for written communication. ${ }^{51}$ In the notification, the foreign investor shall outline their previous business activities and enclose all documents on the basis of which the ownership structure of the foreign investor and the legal entities having a share therein, as well as the beneficial owner as specified in the act on money laundering and terrorist financing can be established. ${ }^{52}$ The original or certified copies of all documents as well as their certified Hungarian translation shall be enclosed with the notification. ${ }^{53}$ In the course of the procedure, the Minister shall communicate with the foreign investor and the entity acting on its behalf via the contact details specified in the notification. If the foreign investor or the entity acting on its behalf is not reachable via the contact details given in the notification, the consequences thereof shall be borne by the foreign investor. ${ }^{54}$ Obviously, this security review can be a frustrating process for international investors who are not well-prepared.

\section{Ministerial procedure and decision}

The Minister confirms the receipt of the notification within eight days. ${ }^{55}$ The confirmation of the receipt of the notification shall a) specify the day the notification was received, b) indicate the name of the foreign investor making the notification, c) specify whether the

\footnotetext{
49 Act No L of 2013 on the Electronic Security of State and Local Government Organizations.

${ }^{50}$ Art. 3 of the Government Decree.

51 Art. 4 (1) of the Government Decree.

52 Art. 5 (2) of the Act; Art. 4 (2) of Government Decree; Act No LIII of 2017 on the prevention and combating of money laundering and terrorist financing.

53 Art. 4 (3) of the Government Decree.

54 Art. 5 of the Government Decree.

55 Art. 6 (2) of the Act.
} 
notification was of an ownership acquisition, the acquisition of a right of operation or a newly adopted activity, as well as d) include a note that the confirmation only confirms the receipt of the notification and should not be considered as an acknowledgement of the notification as required by the Act. ${ }^{56}$ After receiving the notification the Minister shall check without delay if the notification complies with the requirements. ${ }^{57}$ If the Minister establishes that the notification does not comply with the requirements laid down in the Act or in the Decree, he shall inform the foreign investor of this fact and the reasons thereof in the confirmation of the receipt of the notification and where required call on the investor to remedy the deficiencies.

Obviously, the Minister has the right to call on the investor to remedy the deficiencies during the procedure. If it is necessary, the Minister requests further documents and may give a 45-day deadline for their submission. ${ }^{58}$ If this call has no results, the Minister shall repeat the call once. If the second call has no results either, the Minister - after the expiry of the deadline - shall terminate the proceedings. ${ }^{59}$ In such a case, the Minister informs the investor of the termination.

The Minister then examines whether the acquisition of the interest, the right to operate, using sensitive infrastructure and assets or the taking-up and pursuit of the new activity infringes Hungary's security interests. The review process conducted at ministerial level means that the decision will be influenced by high political and diplomatic considerations. ${ }^{60}$ Neither the Act, nor the Government Decree specifies which criteria are to be used to determine whether the acquisition of shares, the setting up of a branch, the provision of a service or obtaining the right to operate is deemed to be a threat to Hungary's national security interests. Clearly, the Minister shall monitor whether the activities carried out by a foreign investor may pose a real threat to national security interests but, unfortunately, the concept of "security interest" placed at the heart of the regulation is not defined by the Act. In this regard, the conclusion that can be drawn from Article 6(6) of the Act is that a risk to national security can be reasonably assumed if the legal entity acquiring ownership or interest was established for or serves the purpose of concealing this circumstance, making control difficult and circumventing the procedure laid down in the Act. The latter can be assumed especially if the legal entity does not pursue actual economic activity in the state of their registration; there are no verifiable circumstances indicating permanent economic activity such as, specifically, business facilities or employees. It should be emphasized that Article 6(6) of the Act shall only apply to those legal entities registered in a member state of the EU, EEA or in Switzerland in which a non-EU, non-EEA or non-Swiss legal or natural person already has a controlling interest [Art. 1(1) b) of the Act]. In all other cases, the Minister seems to have full discretion when assessing the risk of the investment to national security. Thus, in the case of a Chinese company making investment in Hungary, the Minister is not bound by the provision in Article 6(6) of the Act. However, if the

\footnotetext{
${ }^{56}$ Art. 7 (1) of the Government Decree.

${ }^{57}$ Art. 6 (4) of the Act.

${ }^{58}$ Art. 8 (1) of the Government Decree.

${ }^{59}$ Art. 8 (2) of the Government Decree.

${ }^{60}$ Peragovics (2018), 7.
} 
same Chinese company controls the German company making the investment, then the discretion of the Minister is narrower and he has to look at whether the operations of the foreign investor conceal threats to national security, or make the Minister's assessment more difficult or circumvent the procedure described in the Act. ${ }^{61}$

The Minister may request the opinion of those public bodies that operate in the affected sectors (supervising the activities of national security interests). The organ involved in the procedure shall make a proposal, providing duly detailed justification, for acknowledging the notification or making a prohibiting decision. This proposal shall not be binding on the Minister.

The Minister takes a decision within sixty days. This deadline can - in justified cases be extended by up to sixty days. ${ }^{62}$ The Minister can take two types of decisions. If the Minister establishes the investor's conformity to national security interests, the Minister communicates this conclusion to the investor by confirming the acknowledgement of the notification in writing. If the Minister establishes the investor's non-conformity to national security interests, the Minister prohibits the acquisition of the rights or the pursuit of the new activity (prohibiting decision). ${ }^{63}$ The Minister communicates their prohibiting decision including a simplified justification to the foreign investor in writing. ${ }^{64}$ The simplified justification shall include inter alia the specification of the security interest or scope of the interests violated by the legal transaction. ${ }^{65}$

A remedy is available against a prohibiting decision. The foreign investor may contest such a decision by claiming the violation of essential procedural rules or by challenging the qualification of the investment in public administration proceedings before the Budapest Capital Regional Court (exclusive jurisdiction) ${ }^{66}$ The court shall decide on the application in simplified proceedings. If the court establishes that the law was violated, it shall repeal the decision and oblige the Minister to launch a new procedure. ${ }^{67}$ Therefore, the court is not allowed to overturn the ministerial prohibition; it can only refer the case back to the Minister for reconsideration and it can do so solely on the grounds of procedural mistakes. There is no room for immediate legal protection in the proceedings.

\section{Consequences of the ministerial decision}

The foreign investor may only acquire the ownership or interest after having received the confirmation of the acknowledgement of the notification. In the case of acquisition of interest, the registration in the list of shareholders or members can only take place after the confirmation. The request for the modification of the target company's members' list or the record of shareholders may only be submitted after having obtained the confirmation of the acknowledgement of the notification in writing by the Minister. The foreign

\footnotetext{
${ }^{61}$ Gáspár-Szilágyi (2019), 15.

${ }^{62}$ Art. $6(5)$ of the Act.

${ }^{63}$ Art. 6 (4) of the Act.

${ }^{64}$ Art. 6 (7) of the Act.

${ }^{65}$ Art. 13 (1) of the Government Decree.

${ }^{66}$ Art. 6 (8) of the Act.

${ }^{67}$ Art. 6 (9) of the Act.
} 
investor may not exercise its rights in the target company before the Minister confirms the acknowledgement of the notification in writing.

The contract concluded in order to obtain a right to operate may enter into force only as of the day on which the Minister confirms the notification in writing. In any other case, the contract shall not enter into force. In addition, the Act states that the contract for the acquisition of a right to operate is invalid lacking notification or confirmation of the acknowledgement of the notification. Furthermore, the target company is required to have the new activity removed from the Hungarian company register if the Minister does not acknowledge the notification.

In the case of a prohibiting decision, the foreign investor may not exercise his membership rights in the company, he may not take part in the decision-making, he is not entitled to dividends, etc. Furthermore, the foreign investor must sell its interests or eliminate its influence within three months, while the newly listed activity must be removed from the company register in the case of a prohibiting decision. After the expiry of the deadline, the Hungarian State is entitled to sell the foreign investor's share, which will be encumbered by an ex lege pre-emption right in favour of the Hungarian State throughout the sale.

\section{Administrative control}

Compliance with the notification obligation required by the Act is controlled by the Constitution Protection Office (Alkotmányvédelmi Hivatal). ${ }^{68}$ Depending on the decision of the Constitution Protection Office, an organ concerned on the basis of its scope of duties may be involved in the control. The scope of control extends to the monitoring of data in the company registry and the share register.

Where necessary, the Constitution Protection Office shall inform the Minister in writing and without delay of the facts revealed during the control and propose taking the measures laid down in the Act; the Minister is not bound by this proposal. ${ }^{69}$

If it is established during the control that the foreign investor failed to perform his notification obligations - including the case of failure to notify a change in the data - the Minister obliges the investor to pay a fine of up to HUF 1,000,000 if the foreign investor is a natural person and up to HUF 10,000,000 if the foreign investor is a legal entity. Moreover, where the foreign investor's ownership acquisition, acquisition of a right to operate or performance of the newly adopted activity does not infringe Hungary's security interests the Minister confirms the acknowledgement of the notification. Otherwise, the Minister takes a prohibiting decision. ${ }^{70}$

\footnotetext{
${ }^{68}$ Art. 9 (1) of the Act; Art. 14 (1) of the Government Decree.

${ }^{69}$ Art. 17 of the Government Decree.

${ }^{70}$ Art. 9 (2) of the Act.
} 


\section{Conclusion}

Hungary maintains an open economy and attracting FDI is an important priority for the government, especially in the manufacturing, wholesale and services sectors. Foreign investors in Hungary primarily come from Europe and EU partners have a dominant position among all inward foreign investments. EU law, especially the FDI Regulation provides sufficient protection for Hungary within the European Union, it was foreign investments originating from third countries that made it necessary to put in place a protective mechanism. In key industries no such takeovers took place recently that the Hungarian government would consider hostile or detrimental for national security. Rather, the Hungarian national investment screening Act is part of a broader European tendency in which the protection of sensitive industries and sectors is increasingly considered to warrant a specific legal instrument in the form of investment screening. ${ }^{71}$ The main virtue of these new rules is that the Act and the Government Decree established a single and coherent framework for all previously existed fragmented regulations. In this context, the Hungarian legislation on foreign investment control has become prima facie more transparent.

Unfortunately, however, transparency does not go hand-in-hand with predictability and effectiveness because the review process suffers from a number of shortcomings. The obscurity of essential concepts such as "security interest" and "acquisition of direct or indirect ownership" as well as the absence of objective criteria and instruments for scrutinising activities violating national security interests, the lack of transparency of decision-making, the ministerial competence and, finally, the remedy which is of purely formal nature lead us to conclude that the existing screening mechanism leaves too much room for the high political and diplomatic considerations. The grounds based on which nonEU, non-EEA or non-Swiss foreign investors' investments can be blocked are particularly ambiguous. ${ }^{72}$ There is not yet any experience on how deep and, therefore, effective the screening is and whether it is able to filter investments violating Hungarian security interests. Nevertheless, Hungary's national security review will have an insignificant influence on future foreign investments as a whole.

The Lisbon Treaty formally transferred the competence over FDI agreements to the European Union, which in theory became a unified actor with respect to both outbound and inbound FDI. However, many political and legal ambiguities surround the true extent of the EU's authority and autonomy over foreign investment. ${ }^{73}$ Namely, FDI falls within the field of the common commercial policy. In accordance with point (e) of Article 3(1) TFEU, the EU has exclusive competence with respect to the common commercial policy. The common framework of the EU is without prejudice to the sole responsibility of Member States for safeguarding their national security, as provided for in Article 4(2) TEU. It is also without prejudice to the protection of their essential security interests in accordance with Article 346 TFEU. The decision on whether to set up a screening mechanism or

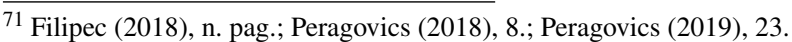

${ }^{72}$ Gáspár-Szilágyi (2019), 21.; Szunomár and Peragovics (2019), 7.

${ }^{73}$ Meunier (2014b), 996-1016.
} 
to screen a particular foreign investment remains the sole responsibility of the Member State concerned, but after 1 October 2020, the entry into force of the EU regulation may raise the need to amend the Hungarian rules. Although the EU regulation does not require Member States to establish national screening mechanisms, but it recommends a few key principles like transparency and non-discrimination if a Member State chooses to adopt one. ${ }^{74}$ As stated in the Regulation, it is important to provide legal certainty for Member States' screening mechanisms on the grounds of security and public order, and to ensure Union-wide coordination and cooperation on the screening of foreign direct investments likely to affect security or public order. The shortcomings we have highlighted may hinder the full accomplishment of these objectives.

\section{References}

Bian, Ch. (2020). National Security Review of Foreign Investment: A Comparative Legal Analysis of China, the United States and the European Union. New York: Routledge. Casarini, N. (2016). When All Roads Lead to Beijing. Assessing China's New Silk Road and its Implications for Europe. The International Spectator, 51(4), 95-108.

De Luca, A. (2015). The EU and Member States: FDI, Portfolio Investments, Golden Powers and SWFs. In Bassan, F. (ed.), Research Handbook on Sovereign Wealth Funds and International Investment Law. London: Edward Elgar Publishing, 178-205.

Dixit, A. (2011). International Trade, Foreign Direct Investment, and Security. The Annual Review of Economics, 3(1), 191-213.

Filipec, O. (2018). Europeanization of FDI Screening: What Model for the EU and its Member States? New Perspectives on Political Economy. n. pag.

Gáspár-Szilágyi, S. (2019). Country Report on Hungary and Romania. In Andreas Moeberg, Steffen Hindelang (eds.). A Common European Law on Investment Screening, Springer, 2020. Retrieved from https://www.academia.edu/39633877/_Investment_Screening Country_Report_on_Hungary_and_Romania.

Gubik, A. S., Sass, M., Szunomár, Á. (2020). Asian Foreign Direct Investments in the Visegrad Countries: What Are Their Motivations for Coming Indirectly? Danube Law and Economics Review, 11(3), 239-252.

Ma, Y., Overbeek, H. (2015). Chinese foreign direct investment in the European Union: explaining changing patterns. Global Affairs, 1(4-5), 441-454.

Matura, T. (2017). Chinese Investment in Hungary: Few Results but Great Expectations. In John Seaman - Mikko Huotari - Miguel Otero-Iglesias (eds.). Chinese Investment in Europe, A Country-Level Approach. French Institute of International Relations, 74-79.

Meunier, S. (2014a). 'Beggars can't be Choosers': The European Crisis and Chinese Direct Investment in the European Union. Journal of European Integration, 36(3), 283-302.

Meunier, S. (2014b). Divide and conquer? China and the cacophony of foreign investment rules in the EU. Journal of European Public Policy, 21(7), 996-1016.

${ }^{74}$ Peragovics (2019), 18. 
Mota, C. E. (2018). A More Targeted Approach to Foreign Direct Investment: The Establishment of Screening Systems on National Security Grounds. Brazilian Journal of International Law, 15(2), 440-466.

Nicolas, F. (2014). China's direct investment in the European Union: challenges and policy responses. China Economic Journal, 7(1), 103-125.

Peragovics, T. (2018). A preliminary assessment on foreign investment screening in Hungary. Világgazdasági Intézet Blogja (30.10.2018). Retrieved July 17, 2019, from https://vilaggazdasagi.blog.hu/2018/10/30/will_hungary_respond_to_european_concerns _on_chinese_foreign_investment_a_preliminary_assessment_on_.

Peragovics, T. (2019). Protection without Protectionism? Foreign Investment Screening in Europe and the V4 Countries Today - A Comparative Analysis. Centre for Economic and Regional Studies HAS Institute of World Economics, Working Paper, Nr. 252, 1-32. Retrieved from http://real.mtak.hu/93242/1/WP252_Peragovics_Protection_without_protectionism.pdf .

Stapleton, C. (2015). The Global Colony: A Comparative Analysis of National SecurityBased Foreign Investment Regimes in the Western Hemisphere. Washington University Law Review, 92(6), 1647-1681.

Salacuse, J. W. (2013). The three laws of international investment: National, contractual, and international frameworks for foreign capital. Oxford: Oxford University Press.

Shields, J. (2018). Smart Machines and Smarter Policy: Foreign Investment Regulation, National Security, and Technology Transfer in the Age of Artificial Intelligence. John Marshall Law Review, 51(2), 279-308.

Szunomár, Á., Peragovics, T. (2019). Hungary: An assessment of Chinese-Hungarian economic relations. In: Kramer, Zack (ed.) Comparative Analysis of the Approach Towards China: V4+ and One Belt One Road S. l. Institute of World Economics, Centre for Economic and Regional Studies, Hungarian Academy of Sciences, Prague Security Studies Institute, Institute of Asian Studies (IAS), Belgrade Fund for Political Excellence (BFPE), Centre for International Relations (CIR), (2019) 2-8.

Varga, G. (2018). Az Európán kívüli világból érkező külföldi múködőtőke a Visegrádi országokban. (Outside European foreign direct investments in the Visegrad countries). Földrajzi Közlemények, 142(2), 110-121.

United Nations Conference on Trade and Development (2008). World Investment Report 2006, Methodological Note. From: https://unctad.org/system/files/official-document/wir2006_en.pdf.

United Nations Conference on Trade and Development (2018). World Investment Report 2018. From: https://unctad.org/system/files/official-document/wir2018_en.pdf.

United Nations Conference on Trade and Development (2019). World Investment Report 2019. From: https://unctad.org/system/files/official-document/wir2019_en.pdf. 